\title{
PELATIHAN PENGOLAHAN SE'I TUNA DENGAN FORTIFIKASI EKSTRAK DAUN JATI DI DESA GAJAHREJO KABUPATEN MALANG
}

\author{
Mikchaell Alfanov Pardamean Panjaitan ${ }^{1,2}$, Eddy Suprayitno ${ }^{1,2}$, Hardoko Hardoko ${ }^{1,2}$, Bambang Budi \\ Sasmito $^{1,2}$, Anies Chamidah ${ }^{1,2}$, Titik Dwi Sulistiyati ${ }^{1,2}$, Yunita Eka Puspitasari ${ }^{1,2}$, Heder Djamaludin ${ }^{1,2}$, \\ Jeny Ernawati Tambunan ${ }^{1,2}$ \\ ${ }^{1}$ Program Studi Teknologi Hasil Perikanan, Fakultas Perikanan dan Ilmu Kelautan, Universitas Brawijaya, Malang, \\ Indonesia \\ ${ }^{2}$ Kelompok Kajian D’FISPRO (Development of Fishery Product), Fakultas Perikanan dan Ilmu Kelautan, Universitas \\ Brawijaya, Malang, Indonesia
}

Mikchaell thp@ub.ac.id, eddysuprayitno@ub.ac.id, hardoko@ub.ac.id, niabbs@yahoo.com, achamidah@yahoo.co.id, titikdwi.s@ub.ac.id, yunita_ep@ub.ac.id, hederdjamaludin@ub.ac.id, jenyetambunan@uba.c.id

\begin{abstract}
Abstrak
Kegiatan Pengabdian kepada Masyarakat ini bertujuan untuk meningkatkan pengetahuan dan keterampilan pelaku UMKM di Desa Gajahrejo Kecamatan Gedangan Kabupaten Malang melalui diversifikasi pengolahan ikan tuna (Thunnus sp.) dalam bentuk se'i tuna dengan fortifikasi ekstrak daun jati. Tujuan kegiatan ini yaitu untuk meningkatkan pengetahuan dan keterampilan serta menumbuhkan sikap positif pelaku UMKM di Pantai Bajul Mati, Desa Gajahrejo, Kabupaten Malang terhadap usaha diversifikasi pengolahan produk berbahan ikan tuna. Metode yang digunakan pada kegiatan pengabdian kepada masyarakat ini adalah metode PALS (Participatory Action Learning System) dengan cara pelatihan langsung yang meliputi pengolahan ikan menjadi se'i tuna dengan penambahan ekstrak daun jati sebagai pewarna alami untuk mengubah tampilan produk se'i tuna menjadi lebih menarik dan pengemasan produk olahan se'i tuna. Hasil kegiatan ini menunjukkan bahwa kelompok mitra telah mampu dalam melakukan pengolahan ikan tuna menjadi produk se'i tuna dengan adanya tambahan fortifikan berupa ekstrak daun jati sebagai pewarna alami. Mitra juga telah mampu mengemas produk se'i tuna menggunakan sealer dan vacuum sealer.
\end{abstract}

Kata Kunci: daun jati, diversifikasi, fortifikasi, Se'i, ikan tuna.

\section{PENDAHULUAN}

Sei adalah produk olahan daging khas Kupang Nusa Tenggara Timur yang diolah secara tradisional dengan cara dikuring dilanjutkan dengan pengasapan menggunakan bahan bakar kayu dan daun kusambi (Scheiechera oleosa, Merr) (Djando dan Belyleto, 2018; Buntu, 2020). Kata se'i berasal dari bahasa Rote yang berarti daging tipis yang diiris memanjang (lalolak=lokal) dan diasap. Ada bermacam-macam daging dapat diolah menjadi se'i, tetapi yang umum di Kupang NTT adalah dari daging sapi dan daging babi (Hutasoit et al., 2013). Beberapa tahun belakangan mulai banyak warung atau rumah makan di luar NTT yang menawarkan produk se'i baik dari daging sapi maupun daging babi, dan bahkan ada yang menawarkan se'i daging ayam atau se'i daging kambing. Kondisi ini mengindikasikan bahwa produk se'i dapat diterima oleh masyarakat di luar NTT. Penerimaan masyarakat di luar NTT terhadap produk se'i terkit dengan karakteristik se'i berupa daging panggang 
dengan aroma asap yang lemah, tekstur empuk dan seperti setengah basah tetapi cukup awet (Widiarti et al., 2012). Aroma asap yang lemah ini nampaknya cukup disukai konsumen yang ditandai dengan diterimanya produk se'i di luar daerah NTT. Aroma asap yang tidak kuat ini terkait dengan waktu pengasapan yang tidak lama yaitu sekitar 1 jam (Djando dan Belyleto, 2018). Selain itu juga telah dicoba dengan asap cair dan pemanasan sekitar 1 jam (Supit et al., 2017; Saubaki, 2020).

Karakter lain dari se'i daging adalah warnanya yang bervariasi mulai dari cokelat sampai merah. Warna cokelat berasal dari proses browning saat pemanasan dan pengasapan, sedangkan wana merah diperoleh dari sendawa yang dapat sekaligus sebagai zat pengawet. Karena zat sendawa dianggap bahan kimia yang kurang aman maka muncul penggunaan pewarna alami seperti angkak (Sabtu dan Suyatni, 2015), bunga rosela, dan daun jati (Sipahelut dan Kale, 2018).

Indonesia sebagai negara kepulauan juga menghasilkan berbagai jenis ikan yang salah satunya adalah ikan tuna. Ikan tuna bernilai ekonomis tinggi sehingga banyak diekspor, tetapi ikan tuna yang ukuran kecil yang sering disebut dengan "baby tuna" tidak diekspor tetapi untuk memenuhi pasar dalam negeri. Ikan tuna tersebut sebagian besar dijual segar, dan sebagain kecil diolah menjadi ikan pindang, abon ikan, dan juga ada yang diolah menjadi ikan asap. Hal ini menunjukkan belum banyak dilakukan diversifikasi produk dari ikan tuna. Padahal, ikan tuna merupakan salah satu sumber protein hewani yang banyak dikonsumsi masyarakat, mudah didapat, dan harganya murah. Sekitar $60 \%$ dari asupan protein hewani dalam 18,1 kg dikonsumsi per orang per tahun, frekuensi konsumsinya, jauh melebihi dari sumber makanan hewani lainnya (Belton dan Thilsted, 2014). Ikan tuna mengandung protein antara 22,6-26,2 g/100 g daging dan lemak antara $0,2-2,7 \mathrm{~g} / 100 \mathrm{~g}$ daging. Ikan tuna mengandung mineral berupa kalsium, fosfor, besi, sodium, vitamin A (retinol), dan vitamin B (thiamin, riboflavin, dan niasin) (Hadinoto dan Idrus, 2018).
Namun ikan cepat mengalami proses pembusukan. Oleh karena itu, pengolahan ikan perlu diketahui oleh masyarakat. Untuk mendapatkan hasil olahan yang bermutu tinggi diperlukan perlakuan yang baik selama proses pengolahan, seperti menjaga kebersihan bahan dan alat yang digunakan, menggunakan ikan yang masih segar, serta penggunaan garam yang bersih. Pengolahan dan pengemasan produk berbahan ikan merupakan salah satu cara untuk menghambat pertumbuhan mikroorganisme (bakteri) pembusuk dan meningkatkan daya simpan (shelf-life) (Iacumin et al., 2017) dan juga meningkatkan nilai ekonomis produk pengolahan ikan (Juhaeri'ah et al., 2020). Pengolahan ikan menjadi nuget, abon, bakso, dan kerupuk merupakan salah satu alternatif penganekaragaman/diversifikasi produk perikanan yang diharapkan dapat diterima oleh masyarakat.

Di Provinsi Jawa Timur, Kabupaten Malang tepatnya di Kecamatan Gedangan, Desa Gajahrejo, Pantai Bajul Mati Desa Gajahrejo merupakan salah satu daerah penghasil tuna sekitar 159,68 ton (BPS, 2019). Jumlah tangkapan ikan tuna yang banyak ini kemudian menjadi potensi bagi warga sekitar dalam pengolahan agar dapat menjadi peluang usaha untuk meningkatkan taraf perekonomian. Namun, masih terdapat kendala berupa minimnya pengetahuan pelaku UMKM di Desa Gajahrejo dalam pengolahan ikan tuna, sehingga produksi ikan yang melimpah belum memberikan kontribusi yang maksimal terhadap kesejahteraan masyarakat.

Pengolahan yang mudah dan barangkali mirip dengan se'i daging adalah ikan asap, tetapi ikan asap kurang disukai karena proses pengolahan ikan asap secara umum cukup lama (3-5 jam) sehingga rasa asapnya cukup kuat. Rasa asap yang kuat ini kurang disukai oleh konsumen. Masalah ikan asap yang lain adalah proses pengasapan umumnya dalam bentuk utuh atau dibelah sehingga cukup mengganggu konsumen oleh adanya duri yang cukup merepotkan dalam mengkonsumsi, dan bentuk yang masih utuh menyulitkan dalam pengemasan. Permasalahan lain adalah warna daging ikan adalah putih sedangkan daging untuk sei termasuk daging merah, oleh karena itu perlu rekayasa agar warna ikan asap bisa mirip dengan sei sehingga bisa disebut sei tuna. 
Hasil analisis situasi dan potensi unggulan di Desa Gajahrejo, Kecamatan Gedangan, Kabupaten Malang maka diidentifikasi beberapa permasalahan di masyarakat, pertama adalah lemahnya pengetahuan teknis potensi diversifikasi olahan ikan. Kedua adalah belum adanya Teknologi Tepat Guna dalam rangka penyeliaan dan transfer teknologi proses. Ketiga adalah warga belum pernah diberikan pelatihan mengenai penatalaksanaan pengelolaan usaha olahan ikan, menjadi bahan pangan yang bergizi dan nilai ekonomis yang tinggi.

Berdasarkan hal tersebut, maka diperlukan suatu inovasi mengenai diversifikasi produk dari ikan tuna yang memiliki penampilan lebih menarik, mudah dan praktis untuk disiapkan, serta lezat untuk dinikmati. Bentuk makanan olahan dari ikan tuna ini akan cocok yang diusulkan dalam program ini adalah se'i tuna dengan fortifikasi daun jati sebagai pewarna alami. Kegiatan ini diselenggarakan untuk meningkatkan pengetahuan dan keterampilan serta menumbuhkan sikap positif pelaku UMKM di Pantai Bajul Mati, Desa Gajahrejo, Kabupaten Malang terhadap usaha diversifikasi pengolahan produk berbahan ikan tuna.

\section{METODE}

Metode yang digunakan pengabdian masyarakat tentang pengolahan se'i ikan tuna yang difortifkasi ekstrak daun jati adalah metode sistem pembelajaran dengan partisipasi aktif/PALS (Participatory Action Learning System). Metode ini diterapkan untuk pemberdayaan kepada masyarakat khususnya kelompok UMKM di Pantai Bajul Mati, Desa Gajahrejo, Kabupatan Malang sebagai mitra PKM.

PALS diterapkan sejak persiapan bahan, pengolahan se'i dengan alat pengasap, dan pengemasan se'i. Metode ini dilakukan dengan memberikan informasi melalui metode ceramah dan diskusi serta pelatihan langsung tentang penerapan iptek dalam pengembangan komoditi lokal ikan tuna.

Pengabdian masyarakat ini terdiri atas 3 tahapan kegiatan yaitu (1) optimasi pembuatan se'i tuna di laboratorium, (2) pemberian materi mengenai teknik pengolahan se'i tuna dan (3) praktik pengolahan se'i tuna.

\section{Pemberian Materi Pengolahan Se’i Tuna}

Pemberian materi kegiatan dilaksanakan oleh dosen Program Studi Teknologi Hasil Perikanan FPIK, Universitas Brawijaya, sedangkan peserta adalah masyarakat khusunya pelaku usaha di kawasan Pantai Bajul Mati Desa Gajahrejo Kecamatan Gedangan Kabupaten Malang. Pemberian materi dilakukan secara langsung dengan metode ceramah dan diskusi.

\section{Praktik Pengolahan Se'i Tuna}

Praktik pengolahan se'i tuna diarahkan oleh dosen Program Studi Teknologi Hasil Perikanan FPIK, Universitas Brawijaya, dan langsung dipraktik langsung terkait pengoahan sei tuna dilakukan oleh masyarkat khusunya pelaku usaha di kawasan Pantai Bajul Mati, Desa Gajahrejo, Kecamatan Gedangan, Kabupaten Malang.

Bahan yang digunakan yaitu daun jati segar $500 \mathrm{~g}$, air $1500 \mathrm{~mL}$, ikan tuna $500 \mathrm{~g}$, garam $15 \mathrm{~g}$, gula merah $50 \mathrm{~g}$, bawang putih $35 \mathrm{~g}$, bawang merah $25 \mathrm{~g}$, merica $4 \mathrm{~g}$ dan ketumbar $7 \mathrm{~g}$. Cara pembuatan se'i tuna dengan fortifikasi ekstrak daun jati yakni pertama, daun jati $500 \mathrm{~g}$ dihaluskan dengan blender ditambahkan air dengan perbandingan 1:3, saring larutan daun jati dengan menggunakan kain saring. Larutan ekstrak daun jati direbus hingga mendidih dan didiamkan selama 24 jam dan disaring kembali. Larutan ekstrak daun jati dapat digunakan. Kedua, bumbu disiapkan dengan menghaluskan bawang putih, bawang merah, merica dan ketumbar dan gula merah. Ketiga, ikan tuna segar disiangi, difillet dan dibuang kulitnya. Larutan daun jati ditambahkan sebanyak $250 \mathrm{~mL}$, ditambahkan bumbu halus dan rendam ikan selama 24 jam. Keempat, ikan ditiriskan dan di letakkan di rak pengasapan untuk diasap sekitar 45-60 menit (hingga daging matang dan ikan berwarna cokelat kemerahan). Ikan siap dikemas dengan plastic dan diseal. 


\section{HASIL DAN PEMBAHASAN}

Pengabdian kepada masyarakat yang diselenggarakan oleh dosen Program Studi Teknologi Hasil Perikanan (PS THP) FPIK, Universitas Brawijaya, bekerjasama dengan Dinas Kelautan dan Perikanan Kabupaten Malang, dilaksanakan pada tanggal 15 September 2021 bertempat di Pantai Bajul Mati, Desa Gajahrejo, Kabupaten Malang. Peserta pelatihan merupakan pelaku UMKM di Pantai Bajul Mati. Peserta UMKM yang hadir sebagai peserta pelatihan merupakan gabungan dari 3 UMKM yaitu UMKM Pantai Bajul Mati, UMKM Pantai Tamban dan UMKM Pantai Goa Cina dengan jumlah keseluruhan peserta 29 orang terdiri atas dosen PS THP FPIK UB, staf DKP Kabupaten Malang dan pelaku UMKM. Kegiatan terdiri atas tiga aktivitas utama yaitu optimasi pembuatan se'I di laboratorium, pemberian materi dan praktik langsung pengolahan se'i tuna dengan fortifikasi ekstrak daun jati sebagai pewarna alami.

\section{Pemberian Materi Pengolahan Se'i Tuna}

Pemberian materi dilaksanakan oleh dosen PS THP FPIK, Universitas Brawijaya, sedangkan peserta adalah masyarakat khusunya pelaku usaha di kawasan Pantai Bajul Mati Desa Gajahrejo Kecamatan Gedangan, Kabupaten Malang. Pemberian materi pengolahan se'i tuna dilaksanakan dalam bentuk ceramah dan diskusi selama 1 jam. Kegiatan ini memunculkan antusias pelaku UMKM untuk mengetahui cara peningkatan kualitas tuna dengan cara mengolah menjadi produk se'i dengan fortifikasi/penambahan bahan pewarna alami berupa ekstrak daun jati (Gambar 1).

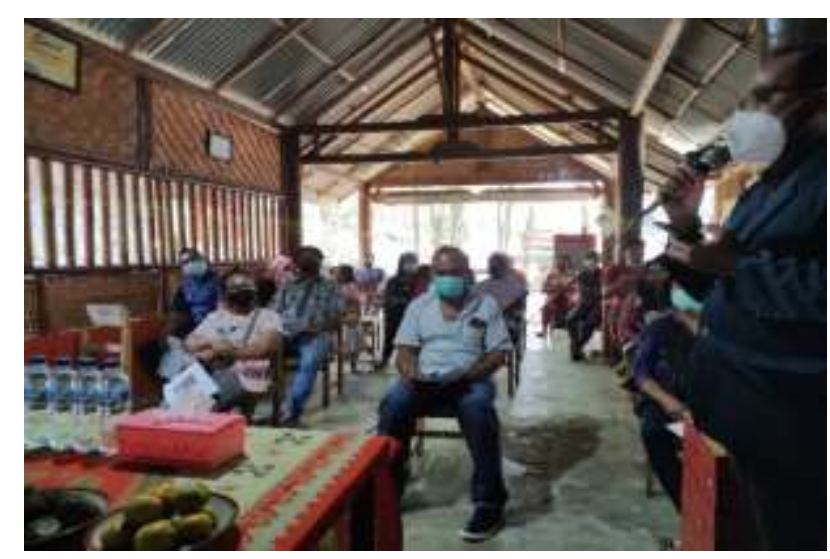

Gambar 1. Pemberian Materi oleh Dosen THP FPIK Universitas Brawijaya

Gambar 1 menunjukkan kegiatan pemberian materi pengolahan se'i tuna. Karena kegiatan ini dilaksanan saat pandemi COVID-19, maka protokol kesehatan tetap dilaksanakan seperti menggunakan masker dan jaga jarak, serta mencuci tangan menggunakan sabun di air yang mengalir. Metode yang diterapkan dalam pemberian materi pengolahan se'i tuna yakni dengan metode ceramah. Tujuan dari tahapan ini adalah memberikan dan menambah pengetahuan teoritis masyarakat khususnya pelaku usaha mengenai teknik pengolahan se'i tuna, dimulai dari pemilihan bahan baku berupa ikan tuna yang masih segar, penanganan bahan baku hingga pengolahan menjadi produk se'i. Inovasi baru yang diterapkan pada kegiatan ini yaitu adanya diversifikasi produk berupa se'i berbahan dasar ikan. Sejauh ini, produk se'i biasanya menggunakan bahan dasar berupa daging sapi atau daging babi.

Pengabdian pengolahan se'i tuna ini mendapat dukungan dari pihak Dinas Kelautan dan Perikanan (DKP) Kabupaten Malang dan Kepala Desa Gajah Rejo. Hal tersebut karena pelatihan pengolahan se'i tuna sejalan dengan program kerja DKP Kab. Malang yang bertujuan untuk memajukan produk ikan asap dan menjadikannya sebagai ciri khas daerah pantai selatan Malang khusunya di tiga lokasi pantai yaitu pantai Bajul Mati, Tamban dan Goa cina. Unuk mendukung terlaksananya kegiatan ini, pihak DKP memberikan bantuan unit alat pengasap ikan yang diberikan kepada ketiga UMKM yang terlibat (Gambar 2).

Gambar 2 menunjukkan alat asap yang digunakan untuk menghasilkan produk se'i tuna. Bahan rak untuk tempat penyimpanan ikan tuna pada alat asap terbuat dari bahan yang memenuhi food grade, sehingga tidak menimbulkan residu bahan kimia berbahaya bagi Kesehatan dalam produk se'i tuna. Alat asap tersebut terdiri atas 4 rak, dengan masing-masing rak memiliki kapasitas mencapai 10 potong sampel ikan tuna. 


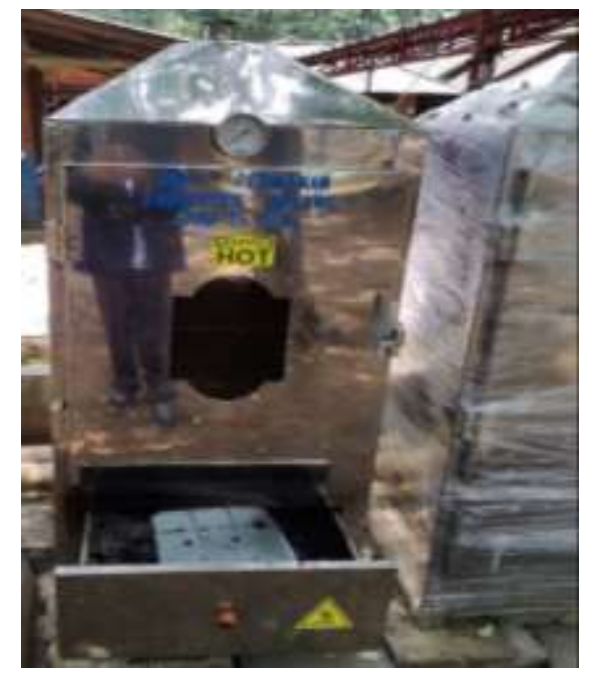

Gambar 2. Alat Asap Bantuan DKP Kabupaten Malang

Selain itu, adanya metode yang diterapkan berupa perbaikan tampilan produk se'i tuna melalui metode fortifikasi ekstrak daun jati sebagai pewarna alami makanan. Pewarna makanan mempunyai beberapa tujuan yaitu memberi kesan menarik bagi konsumen, menyeragamkan dan menstabilkan warna makanan, serta menutupi perubahan warna akibat proses pengolahan dan penyimpanan. Pada kegiatan ini, pewarna alami yang digunakan yaitu ekstrak daun jati karena mengandung pigmen alami, seperti antosianin dan $\beta$-karoten yang dapat berperan sebagai senyawa antioksidan (Suryanti et al., 2020).

Setelah materi pengolahan se'i tuna selesai disampaikan kemudian dilanjutkan dengan kegiatan diskusi dengan peserta pelatihan. Tujuannya untuk memberikan kesempatan kepada para peserta untuk memperoleh informasi lebih detail terkait prosedur pengolahan se'i tuna. Kegiatan selanjutnya yakni praktik langsung pengolahan se'i tuna.

\section{Praktik Pengolahan Se’i Tuna}

Kegiatan praktik diarahkan oleh dosen PS THP FPIK, Universitas Brawijaya, sedangkan praktik pengoahan se'i tuna dilakukan oleh masyarkat khusunya pelaku usaha di kawasan Pantai Bajul Mati Desa Gajahrejo Kecamatan Gedangan Kabupaten Malang. Praktik ini menggunakan bahan baku berupa potongan ikan tuna yang hasil fillet dan skinless yang telah dibumbui dan direndam dengan ekstrak daun jati selama 1x24 jam (Gambar 3).

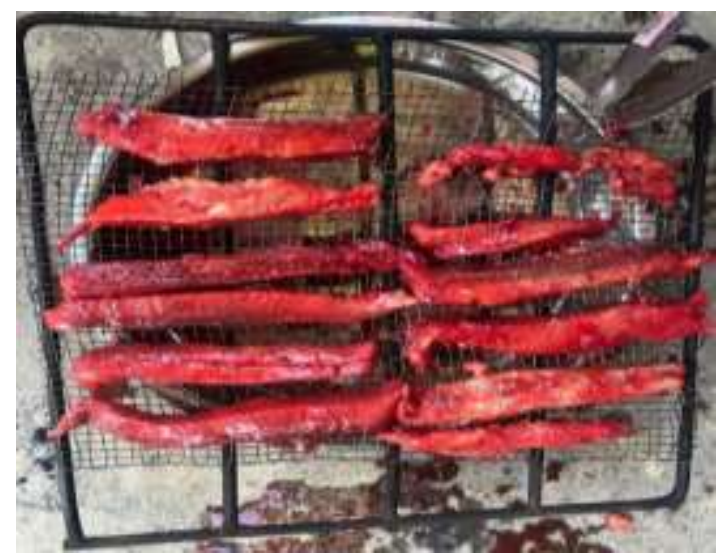

Gambar 3. Penambahan Bahan Pewarna Alami pada Se'i Tuna

Kegiatan praktik dilakukan secara langsung dengan bantuan menggunakan berbagai alat pengolahan se'i tuna (Gambar 2, Gambar 3, Gambar 4, Gambar 5, dan Gambar 6). Tujuan dari tahapan ini adalah melatih secara langsung keterampilan masyarakat khususnya pelaku UMKM terkait keahlian dalam pengolahan se'i tuna, dimana keahlian ini didukung dengan ketersediaan alat asap yang memadai. Gambar 4 menunjukkan antusias dari peserta pelatihan yang berdiskusi dengan dosen UB terkait proses pengolahan se'i tuna.

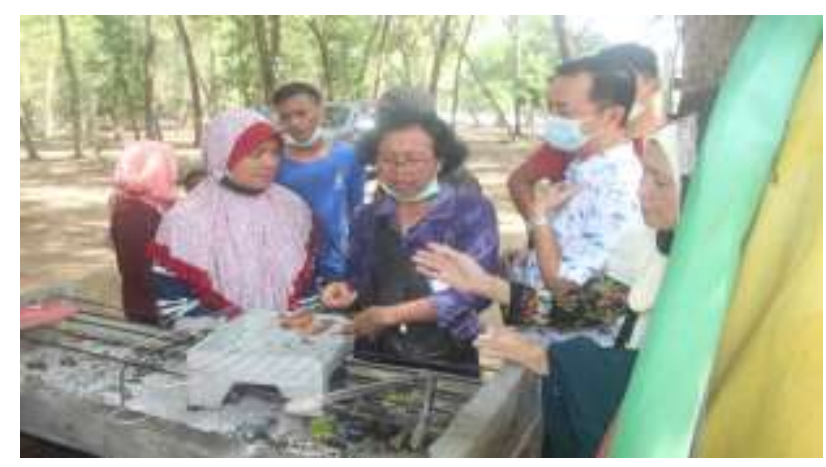




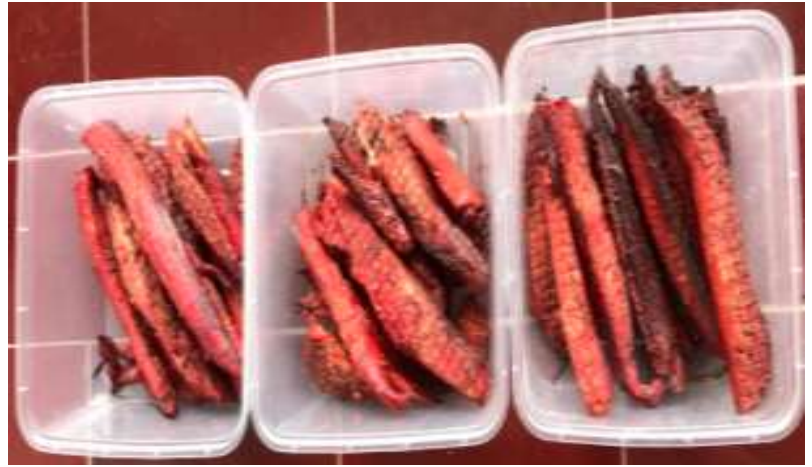

Gambar 5. Produk Akhir Se’i Tuna

Gambar 5 menunjukkan produk se'i tuna yang dihasilkan memiliki tampilan yang menarik dan berwarna merah "menyerupai" warna produk se'i berbahan daging sapi. Warna merah ini merupakan efek dari perendaman menggunakan ekstrak daun jati. Alasan penggunaan ekstrak daun jati sebagai pewarna alami produk se'i tuna karena mudah diperoleh di sekitar Kecamatan Gedangan. Selain itu, ekstrak daun jati aman sebagai pewarna alami makanan sesuai dengan laporan Hamdin et al. (2019) bahwa esktrak daun jati (Tectona grandis) sebagai bahan pewarna makanan tidak memberikan efek toksik pada tikus jenis Wistar secara in vivo. Tampilan warna yang menarik dari produk se'i tuna menunjukkan bahwa kelompok mitra telah mampu dalam pengolahan ikan tuna menjadi produk se'i tuna dengan adanya tambahan fortifikan berupa ekstrak daun jati sebagai pewarna alami makanan.

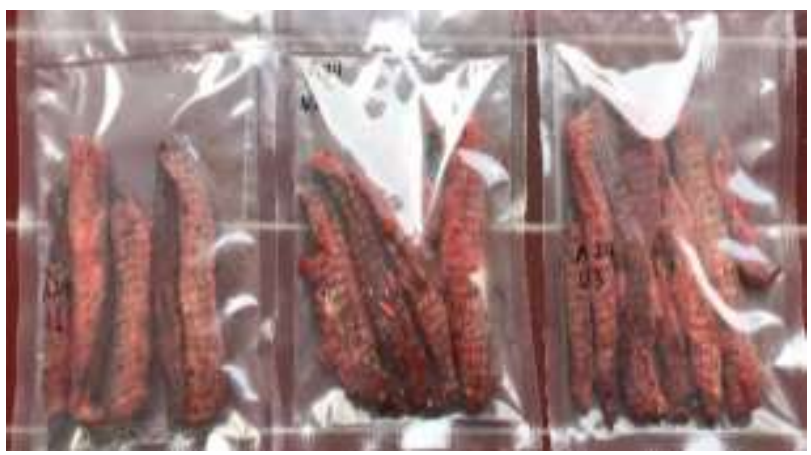

Gambar 6. Produk Se'i Tuna yang Telah Dikemas

Gambar 6 menunjukkan produk se'i tuna yang telah dikemas. Peserta pelatihan menjadi terampil dalam mengemas produk se'i ikan tuna menggunakan alat berupa vacuum sealer. Setelah produk se'i tuna matang, selanjutnya dikemas menggunakan metode vacuum dengan bantuan alat sealer. Hal ini bertujuan untuk menjaga agar produk se'i tuna memiliki daya simpan dalam jangka waktu yang cukup lama.

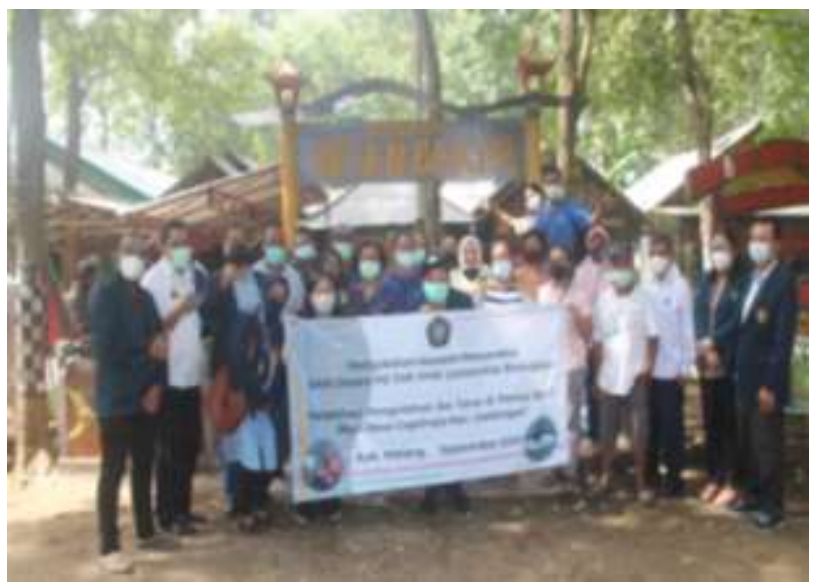

Gambar 7. Foto Bersama Panitia dan Peserta

\section{KESIMPULAN DAN SARAN}

Kegiatan pengabdian ini dapat meningkatkan pengetahuan dan keterampilan mitra dalam mengolah ikan tuna menjadi produk se'i tuna dengan fortifikasi ekstrak daun jati dan meningkatkan pengetahuan mitra dalam pengemasan produk dengan aman dan menarik agar dapat bersaing dengan produk sejenis lainnya.

Produk se'i tuna cukup mudah diolah dan tampilan berupa warna cokelat kemerahan yang cukup menarik, dan rasa yang dapat divariasi oleh komposisi bumbunya.

Saran yang dapat diberikan yaitu perlu dilakukan follow-up kegiatan pelatihan tentang proses memperoleh izin penjualan produk dari BPOM sehingga dapat meningkatkan kepercayaan masyarakat terhadap produk olahan ikan berupa se'i

Pendidikan 647 
tuna yang diproduksi oleh UMKM di pantai selatan Desa Gajahrejo, Kecamatan Gedangan, Kabupaten Malang.

\section{UCAPAN TERIMA KASIH}

Ucapan terima kasih disampaikan kepada Universitas Brawijaya khususnya Badan Penelitian dan Pengabdian kepada Masyarakat (BPPM) Fakultas Perikanan dan Ilmu Kelautan (FPIK) yang telah memberikan hibah untuk pelaksanaan kegitan ini. Ucapan terima kasih juga disamapaikan kepada Dinas Kelautan dan Perikanan (DKP) Kabupatean Malang, kelompok mitra UMKM di Pantai Bajul Mati dan jajaran perangkat Desa Gajahrejo, Kecamatan Gedangan, Kabupaten Malang yang sangat membantu dalam pelaksanaan kegiatan ini.

\section{REFERENSI}

Badan Pusat Statistik [BPS]. (2019). Badan Pusat Statistik Kabupaten Malang 2019.

Belton, B., \& Thilsted, S.H. (2014). Fisheries in transition: Food and nutrition security implications for the global south. Global Food Security, 3(1), 59-66.

Buntu, Y. (2020). Penggunaan kayu Kosambi (Schleichera oleosa) dalam pengasapan daging se'i babi terhadap karakteristik, masa simpan, dan aseptabilitas. Bandung: Program Pendidikan Magister Program Studi Ilmu Peternakan, UNPAD. Thesis.

Djando, Y.A.S., \& Beyleto, V.Y. (2018). Pengaruh lama pengasapan menggunakan daun kosambi (Schleichera oleosa) terhadap keempukan, susut masak, $\mathrm{pH}$, dan daya ikat air daging babi pedaging. Journal of Animal Science, 3(1), 8-10.

Hadinoto, S., \& Idrus, S. (2018). Proporsi dan kadar proksimat bagian tubuh ikan tuna ekor kuning (Thunnus albacares) dari Perairan Maluku. Majalah BIAM, 14(2), 51.

Hamdin, C.D., Eka, S.P., Sinta, W.U., Dandiko, G., Dheny, C.S., Arief, N., Retno, M., Ahmad, J., \& Haji, S. (2019). Acute toxicity of indonesian natural food colorant Tectona grandis leaf extract in wistar rats. J. Med. Sci., 19(2), 69-74.

Hutasoit, K., Suarjana, I.G.K., \& Suada, I.K. (2013). Kualitas daging se'i sapi di Kota Kupang ditinjau dari jumlah bakteri coliform dan kadar air. Indonesia Medicus Veterinus, 2(3), 248260.

Iacumin, L., Erica, T., Marisa, M., \& Giuseppe, C. (2017). Shelf-life evaluation of sliced cold-smoked rainbow trout (Oncorhynchus mykiss) under vacuum (PV) and modified atmosphere packaging (MAP). Turkish Journal of Fisheries and Aquatic Sciences, 17, 1279-1285.

Juhaeri'ah, Maulida, R.M., Nurul, M., \& Wariata, I.W. (2020). Si garang (stik ikan pringgajurang) sebagai upaya meningkatkan nilai ekonomi hasil produksi ikan di Desa Pringgajurang Kecamatan Montong Gading Kabupaten Lombok Timur. Jurnal Warta Desa, 2(1), 110-117.

Sabtu, B., \& Suryatni, N.P.F. (2015). Kualitas kimia daging se'i yang diberi ekstrak angkak dan lama penyimpanan berbeda. Jurnal Nukleus Peternakan, 2(1), 7-14.

Saubaki, M.Y. (2020). Produksi asap cair kayu Kesambi (Schleichera oleosa Merr) dan aplikasinya sebagai flavouring daging Se'i. PARTNER, 20(2), 115-126.

Sipahelut, G.M., \& Kale, P.R. (2018). Penggunaan ekstrak rosella kering beku (Hibiscus sabdarifa Linn) dalam pembuatan daging se'i: Pengaruh lama simpan terhadap sifat fisik, kimia mikrobiologi, dan cita rasa. Jurnal Nukleus Peternakan, 5(1), 49-55.

Supit, M.A.J, Gasong, L., \& Badewi, B. (2017). Aplikasi berbagai asap cair encer dari limbah industri kerajinan kayu terhadap aroma dan cita rasa daging se'i. PARTNER, 17(1), 51-60.

Suryanti, V., Kusumaningsih T., Marliyana S.D., Setyono, H.A., \& Tirsnawati, E.W. (2020). Identification of active compounds and antioxidant activity of teak (Tectona grandis) leaves. Biodiversitas, 21(3), 946-952. 